\title{
Spectrum of droplets produced by use of adjuvants
}

\author{
Espectro de gotas en la pulverización con adición de adyuvantes \\ Robson S. Sasaki ${ }^{*}$, Mauri M. Teixeira ${ }^{1}$, Cleyton B. Alvarenga ${ }^{1}$, Humberto Santiago ${ }^{1}$, \\ Christiam F. S. Maciel $^{1}$
}

\begin{abstract}
Adjuvants are products added to spray solution in order to attend the pesticides application. However, their effects in the technical parameters of the spray are not yet fully understood. The objective was to evaluate the effects of addition of five adjuvants (A, B, $\mathrm{C}, \mathrm{D}$ and $\mathrm{E}$ ) and five dilutions (D1 = 30; D2 = 40; D3 = 50; D4 = 60 e D5 $=70 \mathrm{~mL}$ per 100 liters of water), and a control (distilled water) in the technical parameters of the spraying $\left(\mathrm{Dv}_{0.1} ; \mathrm{Dv}_{0.5} ; \mathrm{Dv}_{0.9}\right.$ and Span index $)$. The analysis of the droplet spectrum was performed using the droplet particle size analyzer (Spraytec, Malvern Instruments Co.), focal lens of $750 \mathrm{~mm}$. The spraying was performed by $\mathrm{CO}_{2}$ pressurized sprayer with a spray nozzle XR $11002 \mathrm{VK}$. The sprayings were performed at pressure of $300 \mathrm{kPa}$. It was observed that there is not a linear relation between dilution and product, regarding the technical parameters of the spraying. As for the parameter $\mathrm{Dv}_{0.5}$ the highest value observed was for the product $\mathrm{C}$ on the dose D5 with $232.4 \mu \mathrm{m}$, while the control had an average of $148.99 \mu \mathrm{m}$. In assessing the SPAN index of the different products and dosages tested, they did not improve significantly compared to the control.
\end{abstract}

Key words: pesticides application technology, droplets diameter, surfactants.

\section{RESUMEN}

Los adyuvantes son productos añadidos a la solución de pulverización con el objetivo de auxiliar en la aplicación de pesticidas. Sin embargo, sus efectos en los parámetros técnicos de la pulverización aún no están totalmente aclarados. Siendo así, el objetivo fue evaluar los efectos de la adición de cinco adyuvantes $(A, B, C, D$ y $Y$ ) y cinco diluciones $(D 1=30 ; D 2=40 ; D 3=50 ; D 4=60$ y $D 5=70 \mathrm{ml}$ por 100 litros de agua), y más el testigo (agua destilada) en los parámetros técnicos de la pulverización ( $D v_{0,1} ; D v_{0,5}$; $D v_{0,9}$ y Amplitud relativa). El análisis del espectro de gotas fue realizado utilizándose un analizador láser de partículas en tiempo real (Spraytec, Malvern Instruments Co.), lente focal de $750 \mathrm{~mm}$. Las pulverizaciones fueron realizadas con un pulverizador a presión constante $\left(\mathrm{CO}_{2}\right)$ dotado de una punta XR 11002 VK. Todas las pulverizaciones fueron realizadas a presión de $300 \mathrm{kPa}$. Se observó que no existe una relación lineal entre dilución y producto en relación con los parámetros técnicos de la pulverización. Con respecto al parámetro $D v_{0,5}$, el mayor valor observado fue para el producto $C$ en la dosis D5 con 232,4 $\mu$ m, siendo que el testigo presentó un valor medio de 148,99 $\mu \mathrm{m}$. En la evaluación de la amplitud relativa, los diferentes productos y dosis probados no mejoraron significativamente, comparados al testigo.

Palabras clave: tecnología de aplicación de agrotóxicos, diámetro de gotas, surfactantes.

\section{Introduction}

The history of agricultural adjuvants has been reported since the beginning of the $18^{\text {th }}$ and $19^{\text {th }}$ centuries when additives such as, pine resins, wheat flour, molasses and sugar were used with lime, sulfur, copper, and arsenates to improve the biological activity through physical and chemical modifications of the spray solutions (Green and Beestman, 2007).
The pesticide application technology aims to place the product on the target, with the lowest possible losses. Several factors such as choice of spraying, type and flow rate of the spray nozzle, product to be sprayed, time to spray, weather, and droplets population spectrum determine the application efficiency. The droplet spectrum consists to separate droplets in size classes, and the main parameters are the volume median diameter (VMD), the number median diameter (NMD) and SPAN index.

\footnotetext{
1 Universidade Federal de Viçosa, Department of Agricultural Engineering, Viçosa-MG.

* E-mail: robsonsasaki@yahoo.com.br
}

Fecha de Recepción: 07 Febrero, 2012.

Fecha de Aceptación: 10 Septiembre, 2012. 
The VMD is the droplet diameter which divides the volume of a droplet population into two equal parts. Usually this parameter is used to express the size of the spray droplets and the lower is this value, to a certain limit, greater is the chance to hit the target and increases the droplets density. However, droplets below $100 \mu \mathrm{m}$ may cause losses by offtarget spray drift, and on the other hand, droplets larger than $600 \mu \mathrm{m}$ may cause losses by run-off (Cunha et al., 2004).

The SPAN index allows inference of the uniformity on the droplet spectrum. More homogeneous is the spectrum greater will be the chances of a quality spraying. In recent years it has increased the addition of adjuvants to the spray solution. According to Minguela and Cunha (2010), adjuvants are compounds without phytosanitary properties, added to the pesticides formulations or spray solutions, to facilitate the implementation, to increase efficiency and to make a safer use of the product.

Many works are conducted for the purpose to study the effects of the use of adjuvants on deposition of pesticides on the target and its effect on droplet size. According to Carbonari et al. (2005), the addition of surfactants to the spray solution provided an increase of deposition of the product on Cynodon dactylon. According to Cunha and Peres (2010), to control Asian soybean rust, foliar disease caused by the fungus Phakopsora packyrhizi, the addition of adjuvants increased the droplets density, on the middle portion and on the top of the plant canopy and, consequently resulting in higher productivity.

Other studies have indicated that there is an increasing effect of adjuvants on spraying droplet spectrum. The addition of polyester copolymer surfactant and silicone to the spray solution increased the droplet size (Iost, 2008). Cunha et al. (2003), in order to investigate strategies to reduce drift has been concluded that the addition of vegetable oil to the spray solution increases the diameter of spray droplets and reduces the percentage of droplets subject to wind action becoming therefore into an effective factor in drift reduction. The polymer adjuvants can increase droplet size from $45 \%$ to $145 \%$ compared to pure water (Spanoghe et al., 2007).

In aerial application, Wolf and Gardisser (2003), evaluating the effect of the addition of adjuvants to the spray solution, found that some products had anti-drift action while others adjuvants increased the potential risk of losses by off-target spray drift.
On the other hand, Mota et al. (2010) affirmed that increasing the dose of adjuvant reduces significantly the volume median diameter, and similar results were obtained by Spanoghe et al. (2004) using the commercial adjuvants Agral 90 and Break Through S240 in the concentrations of 100 and $1000 \mathrm{mg}$ $\mathrm{L}^{-1}$, respectively.

In a research conducted with different adjuvants Oliveira (2011) found that $91 \%$ of the tested products reduced the size of droplets as the dose was increased and only 9\% increased the VMD increasing the concentration of the products on the spray solution. In contrast Zhu et al. (1997) observed that the droplet size produced by traditional hydraulic nozzles increased proportionally as the dose of the polyacrylamide based adjuvant was increased on the spray solution.

Thus, the aim of this work was to evaluate the effect of the use of adjuvants on droplets spectrum in a spraying.

\section{Materials and Methods}

The study was conducted at the Laboratory of Agricultural Pesticides Application (LADA), Department of Agricultural Engineering, Universidade Federal de Viçosa, Viçosa-MG. The psychrometric conditions during the experiment were temperature between 25 and $28^{\circ} \mathrm{C}$, air relative humidity of $65 \%$ and no wind.

The experimental design was completely randomized in factorial scheme $(5 \times 5+1)$, where 5 products, not identified by trade issues, were designated by letters of the alphabet (A, B, C, D and $\mathrm{E}$ ), and five dilutions, designated by the capital letter "D" as follows: $\mathrm{D} 1=30 ; \mathrm{D} 2=40 ; \mathrm{D} 3=50$; $\mathrm{D} 4=60$ e D5 $=70 \mathrm{~mL}$ per 100 liters of water, and a control (distilled water), with four replications per treatment.

The products used are well characterized: Product "A" is a vegetable oil, consisting of $892 \mathrm{~g} \mathrm{~L}^{-1}$ fatty ester and 3\% inert, belonging to the spreader class of the ester group. Considered as an adhesive, it was recommended at $0.5 \%$ of the spray solution volume. The product " $\mathrm{B}$ " consists of $105 \mathrm{~g} \mathrm{~L}^{-1}$ of $\mathrm{N}$, density of $1050 \mathrm{~g} \mathrm{~L}^{-1}$, pH 6-7 in the recommended dilution of 25 to $50 \mathrm{~mL} / 100 \mathrm{~L}$ of spray solution. The product " $\mathrm{C}$ " formulation is based on Lauryl Ether Sodium Sulfate, being classified as a surfactant, sequestrant and emulsifier. The product D consists of $105 \mathrm{~g} \mathrm{~L}^{-1}$ of $\mathrm{N}$ and $52.5 \mathrm{~g} \mathrm{~L}^{-1}$ of $\mathrm{P}_{2} \mathrm{O}_{5}$, 
density of $1050 \mathrm{~g} \mathrm{~L}^{-1}, \mathrm{pH} 2-3$, and it has features to prevent foaming in the tank, anti-drift, sequestrant of cations and $\mathrm{pH}$ reducer, and the recommended dilution is 25 to $50 \mathrm{~mL} / 100 \mathrm{~L}$ of spray solution. The product $\mathrm{E}$ is composed of $34.5 \mathrm{~g} \mathrm{~L}^{-1}$ of N and $207 \mathrm{~g}$ $\mathrm{L}^{-1}$ of $\mathrm{P}_{2} \mathrm{O}_{5}$, density of $1150 \mathrm{~g} \mathrm{~L}^{-1}, \mathrm{pH}$ between 1 and 2 , and in accordance with the manufacturer, it has as main features the spray solution $\mathrm{pH}$ reducer and it stabilizes the cations $\mathrm{Fe}^{2+}, \mathrm{Ca}^{2+}$ and $\mathrm{Mg}^{2+}$ in the water. It has as secondary features to increase the droplets penetration, to prevent foaming in the tank, to prevent drift and evaporation, and the recommended dilution is between 25 to $50 \mathrm{~mL} / 100$ $\mathrm{L}$ of spray solution.

The spraying was performed using a $\mathrm{CO}_{2}$ pressurized sprayer. The spray nozzle used was XR 11002VK manufactured by TeeJet. Before starting the tests, the spray nozzle was assessed in accordance to ISO 10625, and also the manometer used in the test was gauged by a standard manometer Class A3. The operating pressure adopted in the study was $300 \mathrm{kPa}$.

The droplets spectrum analysis was performed using the droplet particle size analyzer (Spraytech, Malvern Instruments Co.) this device has a focal lens of $750 \mathrm{~mm}$ which is based on light path diffraction when it collides with the droplets. In this system the droplets diameter is proportional to the angle due to the diffraction suffered by the light. The spray nozzle was installed at $0.4 \mathrm{~m}$ from the laser beam, and it was moved to expose all the spray to the laser beam. The laser analyzer was set to count drops from 0.10 to $2,500 \mu \mathrm{m}$.

The variables of the spray droplet spectrum evaluated were $\mathrm{Dv}_{0.1}, \mathrm{Dv}_{0.5}, \mathrm{Dv}_{0.9}$ and SPAN index. Statistical analysis was performed by the software Assistat (version 7.6 beta), following the traditional model of factorial with additional control, similar to that proposed by Gomes (1990). According to this model, the tests applied to the treatments were Dunnett's test $(\mathrm{p}<0.05)$ to compare the adjuvant and the water and Tukey's test $(\mathrm{p}<0.05)$ only between treatments using adjuvants.

\section{Results and Discussion}

The hydraulic nozzle used in the test had the flow rate checked at $300 \mathrm{kPa}$ working pressure and corresponded to $0.78 \mathrm{~L} \mathrm{~min}^{-1}$, which is consistent with the specified by the nozzle manufacturer and with the colour coding specified by ISO 10625 .
To gauge the manometer, it was obtained the Equation 1, which enabled the correction on the reading of the $\mathrm{CO}_{2}$ pressurized sprayer manometer. The equation determination coefficient was 0.9998 .

$$
y=0.9958 x+35.42
$$

where:

$\mathrm{y}=$ the standard manometer pressure $(\mathrm{kPa})$;

$\mathrm{x}=$ the $\mathrm{CO}_{2}$ pressurized sprayer manometer pressure $(\mathrm{kPa})$.

The $\mathrm{Dv}_{0.1}$ represents the droplet diameter such that $10 \%$ of the volume of liquid sprayed is made up of droplets smaller than this value. In assessing the parameter $\mathrm{Dv}_{0.1}$, there was no interaction between product and dilution when applying the $\mathrm{F}$ test $(\mathrm{p}<0.005)$. As there was no interaction, product and dilution factors were examined separately, and only the products factor was significant by $\mathrm{F}$ test, allowing the application of the Tukey test for comparison between means. In the comparison between treatments with adjuvants and water there was significant effect for some products. The results of the Tukey test indicated that the product " $B$ " and "A" respectively showed higher $\mathrm{Dv}_{0.1}$, while comparing to water the products " $A$ ", "B" and " $E$ " had at least one dilution with results statistically different (Table 1).

The size of $\mathrm{Dv}_{0.1}$ interfered directly on the SPAN index. The adjuvants " $A$ " and " $B$ " increased the diameter $\mathrm{Dv}_{0.1}$, resulting in an increase of the droplet spectrum homogeneity. Individualize the SPAN, the volume median diameter, coefficient of uniformity, among others parameters to characterize the spray is not recommended because there is the risk of incurring serious errors. However, the droplets homogeneity is undoubtedly an objective to be achieved in any application, regardless of weather conditions, spray nozzle type, operating pressure and spray solution volume. Increasing the $\mathrm{Dv}_{0.1}$ by adjuvant can reduce the SPAN and consequently increase the homogeneity of the spectrum of droplets reducing the number of small droplets, which are difficult to be analyzed through the use of water and oil sensitive papers, and they are very susceptible to drift and to evaporate. Di Oliveira $e t$ al. (2010) agree with this topic. Roman et al. (2009), evaluating the effect of mineral and vegetable oil on droplet size found that the oil based adjuvant 
Table 1. Values of diameter $\mathrm{Dv}_{0.1}(\mu \mathrm{m})$ for the different adjuvants and dilutions.

\begin{tabular}{lllllll}
\hline \multirow{2}{*}{ Product } & \multicolumn{5}{c}{ Dilution $(\mathrm{mL} / 100 \mathrm{~L}$ water $)$} & \multirow{2}{*}{ Mean } \\
\cline { 2 - 6 } & 30 & 40 & 50 & 60 & 70 & $79.30 \mathrm{ab}$ \\
$\mathrm{A}$ & $80.36^{*}$ & $80.56^{*}$ & 77.23 & 75.62 & $82.72^{*}$ & $83.15 \mathrm{a}$ \\
$\mathrm{B}$ & $81.60^{*}$ & $80.52^{*}$ & $80.52^{*}$ & $89.06^{*}$ & $84.06^{*}$ & $68.54 \mathrm{c}$ \\
$\mathrm{C}$ & 65.66 & 63.42 & 74.59 & 67.37 & 71.67 & $70.78 \mathrm{c}$ \\
D & 75.60 & 63.32 & 68.44 & 68.62 & 77.93 & $73.76 \mathrm{bc}$ \\
E & $84.92^{*}$ & 73.25 & 68.35 & 74.73 & 67.55 & 76.78 \\
Mean & 77.63 & 72.21 & 73.83 & 75.08 & & \\
\hline
\end{tabular}

Control

62.80

Means followed by same letter do not differ by Tukey test at $5 \%$ probability.

Means followed by (*) differ of the control by Dunnett's test at $5 \%$ probability (SLD $=17.31$ ).

decreases the droplet size and promotes the spectrum uniformity. Comparing to water all products increased $\mathrm{Dv}_{0.1}$ values however only the products A, B and D differed statistically by Dunnett's test. This result demonstrates that not all of the adjuvants have the ability to increase the size of droplets, especially those small ones.

The parameter commonly used to estimate the droplet size is the $\mathrm{Dv}_{0.5}$ which is also named as volume median diameter (VMD). When evaluated the VMD parameter, there was an interaction between the product and dilution factors when applying the $\mathrm{F}$ test $(\mathrm{p}<0.005)$, allowing to evaluate the interaction by Tukey test at $5 \%$ probability. When evaluating the effect of dilution for a specific product it was observed that the products "A, B and E" there was no significant difference for the different doses tested. For products with a given dilution, the product "A, $\mathrm{B}, \mathrm{C}, \mathrm{D}$ and $\mathrm{E}$ " showed higher VMD in dilutions of
D2, D5, D5, D3 and D1respectively. In comparison with water by Dunnett's test, it was found that only the product "A" had no significant difference in any of the dilutions (Table 2).

The significant results of the interaction between product and dilution to volume median diameter open a wide range of possibilities in the search for the best combination, for optimal droplet size, according to the conditions of each region. The companies provide a large number of products marketed as an adjuvant, but not everyone has the ability to increase the droplets size. The results also show that the droplets size do not increase linearly as increases the adjuvant dose. In a brief review in the scientific literature it shows that most of the works point to an increase in the VMD with the addition of adjuvants to the spray solution (Zhu et al., 1997; Spanoghe et al., 2007). However, there are studies that indicate the opposite, in other

Table 2. Values of diameter $\mathrm{Dv}_{0.5}(\mu \mathrm{m})$ for the different adjuvants and dilutions.

\begin{tabular}{lllllll}
\hline \multirow{2}{*}{ Product } & \multicolumn{5}{c}{ Dilution $(\mathrm{mL} / 100 \mathrm{~L}$ water $)$} & Mean \\
\cline { 2 - 5 } & \multicolumn{1}{c}{30} & \multicolumn{1}{c}{40} & \multicolumn{1}{c}{50} & 60 & 70 & 173.9 \\
$\mathrm{~A}$ & $162.6 \mathrm{bA}$ & $187.2 \mathrm{aA}$ & $177.9 \mathrm{bA}$ & $168.6 \mathrm{aA}$ & $173.3 \mathrm{bA}$ & 200.5 \\
$\mathrm{~B}$ & $206.1 \mathrm{abA} *$ & $181.9 \mathrm{aA}$ & $202.1 \mathrm{abA}$ & $205.1 \mathrm{aA}$ & $207.2 \mathrm{abA} *$ & 202.2 \\
$\mathrm{C}$ & $157.3 \mathrm{bC}$ & $182.6 \mathrm{aBC}$ & $232.4 \mathrm{aAB} *$ & $191.2 \mathrm{aBC}$ & $247.6 \mathrm{aA} *$ & 180.9 \\
$\mathrm{D}$ & $189.3 \mathrm{abAB}$ & $144.3 \mathrm{aB}$ & $208.0 \mathrm{abA} *$ & $168.6 \mathrm{aAB}$ & $194.7 \mathrm{abAB}$ & 185.2 \\
$\mathrm{E}$ & $216.6 \mathrm{aA} *$ & $175.1 \mathrm{aA}$ & $187.9 \mathrm{abA}$ & $177.9 \mathrm{aA}$ & $168.4 \mathrm{bA}$ & 198.2 \\
Mean & 186.4 & 174.2 & 201.7 & 182.3 & \multicolumn{3}{c}{148.99} \\
\hline Water & \multicolumn{7}{c}{} \\
\hline
\end{tabular}

Means followed by same lower case letter in the column and capital letter on the line do not differ between themselves by Tukey test at $5 \%$ probability.

Means followed by (*) differ from the control by Dunnett's test at 5\% probability level (SLD = 56.42). 
words, increasing the concentration of adjuvants to the spray solution decreases the VMD (Mota et al., 2010; Roman et al., 2009).

The addition of adjuvants to the spray solution aims to increase the droplets permanence on the leaf, to reduce evaporation and volatilization losses, to reduce $\mathrm{pH}$, among others. The use of these products to increase the droplets size should not be recommended, since it implies an increase of production costs. A grower to succeed in the droplet size should make the appropriate selection of nozzles to weather conditions, product, water, etc.

Although adjuvants are a tool to help pesticides application, when it is used incorrectly or without knowledge can lead to negative effects. Several factors such as spreading, adhesion and compatibility of these products should be taken into account when choosing them. Lan et al. (2007) commented that the addition of adjuvants alters the applications performance. However, its effect can be positive or negative in relation to the product deposition on the target.

Another spray parameter used to characterize the droplet spectrum is the $\mathrm{Dv}_{0.9}$, which represents the droplet size that $90 \%$ of the volume of liquid sprayed is made up of droplets smaller than this value. In this study, there was no significant interaction between product and dilution, neither testing dilution separately for this variable of droplet spectrum. Only the variable products showed significant effects for the $\mathrm{F}$ test at $5 \%$ probability for this parameter of droplet spectrum, and the product " $\mathrm{C}$ " showed higher $\mathrm{Dv}_{0.9}$. Comparing to water only the product "C" in dilution "D5" had significant effect (Table 3).

The $\mathrm{Dv}_{0.9}$ is an important parameter of droplet spectrum. In the spraying, generally, the number of droplets that make it up is low. However, it is largely responsible for the heterogeneity of droplets population. Just the parameter $\mathrm{Dv}_{0.9}$ in a spraying does not allow the estimation of the spray quality. But when it is correlated with the diameters $\mathrm{Dv}_{0.1}$ and $\mathrm{Dv}_{0.5}$ it gives a precise idea of droplet size uniformity.

The SPAN index uses variables $\mathrm{Dv}_{0.1}, \mathrm{Dv}_{0.5}$ and $\mathrm{Dv}_{0.9}$, and provides to researchers or growers a good idea of the droplet size homogeneity. In the evaluation of SPAN, there was no interaction between the product and dilution factors and evaluating the factors separately, the dilution factor was also not significant, both by the F test $(\mathrm{p}<0.005)$. Though, the product was significant by $F$ test $(p<0.005)$, and allowed the comparison of averages of products tested. The product "A" showed the lowest value of SPAN. Comparing to water none products showed significant differences (Table 4).

The evaluation of the SPAN provides an idea of the droplets spectrum homogeneity (Cunha, et al., 2010). The SPAN is a dimensionless numerical value that expresses the variation of droplet size and more close to zero more homogeneous will be the droplet spectrum. The results indicate that the SPAN values hardly can be got below one using a spray nozzle XR 11002VK. The highest values of SPAN indicate that there was greater variability of the spectrum and in this case the product "C" had the most heterogeneous droplets spectrum.

The droplet particle size analyzer was set up for a range of measurement of droplets considering that all the droplets, regardless of their size, constitute the spectrum. Under laboratory conditions, where the meteorological factors are controlled, this setting was considered ideal. However, Di Oliveira

Table 3. Values of diameter $\mathrm{Dv}_{0.9}(\mu \mathrm{m})$ for the different adjuvants and dilutions.

\begin{tabular}{lllllll}
\hline \multirow{2}{*}{ Adjuvant } & \multicolumn{7}{c}{ Dilution $(\mathrm{mL} / 100 \mathrm{~L}$ water) } & Mean \\
\cline { 2 - 5 } & \multicolumn{1}{c}{30} & \multicolumn{1}{c}{40} & \multicolumn{1}{c}{50} & 60 & \multicolumn{1}{c}{70} & $339.49 \mathrm{~b}$ \\
$\mathrm{~A}$ & 289.65 & 352.88 & 361.95 & 335.6 & 357.4 & $379.09 \mathrm{ab}$ \\
$\mathrm{B}$ & 372.83 & 393.65 & 373.38 & 388.88 & 366.73 & $425.5 \mathrm{a}$ \\
$\mathrm{C}$ & 378.75 & 423.03 & 450.83 & 402.43 & $472.48 *$ & $374.72 \mathrm{ab}$ \\
D & 382.78 & 336.4 & 426 & 312.58 & 415.85 & $366.04 \mathrm{~b}$ \\
E & 420.23 & 316.35 & 370.38 & 356 & 367.25 & 376.8075 \\
Mean & 368.848 & 364.462 & 396.508 & 359.098 & \\
\hline Control & \multicolumn{7}{c}{324.51} \\
\hline
\end{tabular}

Means followed by same letter do not differ by Tukey test at $5 \%$ probability.

Means followed by $(*)$ differ from the control by Dunnett's test at $5 \%$ probability (SLD $=138.18$ ). 
Table 4. Values of SPAN (adm) for the different adjuvants and dilutions.

\begin{tabular}{lcccccc}
\hline \multirow{2}{*}{ Adjuvant } & \multicolumn{7}{c}{ Dilution $(\mathrm{mL} / 100 \mathrm{~L}$ water $)$} & Mean \\
\cline { 2 - 6 } & 30 & 40 & 50 & 60 & 70 & $1.46 \mathrm{~b}$ \\
$\mathrm{~A}$ & 1.23 & 1.44 & 1.6 & 1.46 & 1.56 & $1.48 \mathrm{~b}$ \\
$\mathrm{~B}$ & 1.42 & 1.71 & 1.45 & 1.47 & 1.36 & $1.8 \mathrm{a}$ \\
$\mathrm{C}$ & 1.99 & 2.02 & 1.62 & 1.76 & 1.62 & $1.69 \mathrm{ab}$ \\
$\mathrm{D}$ & 1.62 & 1.89 & 1.72 & 1.45 & 1.75 & $1.59 \mathrm{ab}$ \\
$\mathrm{E}$ & 1.57 & 1.39 & 1.62 & 1.6 & 1.79 & 1.616 \\
Mean & 1.566 & 1.69 & 1.602 & 1.548 & & \\
\hline Control & & & 1.76 &
\end{tabular}

Means followed by same letter do not differ by Tukey test at $5 \%$ probability.

Means followed by $(*)$ differ from the control by Dunnett's test at $5 \%$ probability (SLD $=0.66$ ).

et al. (2010) worked using a narrower range of the spectrum from 0.5 to $900 \mu \mathrm{m}$ using an analyzer with lens of $300 \mathrm{~mm}$.

The results for all variables of the droplet spectrum analyzed have no direct relation in the droplets behavior since it was observed that sometimes there was increasing of droplet size and sometimes there was no increasing. It occurs possibly because there is interaction between the product and the spray nozzle. Cunha et al. (2010) also agree with this statement. It is possible that adjuvant with properties to break the surface tension of water increases the spreading of droplets on the water sensitive papers, overestimating the effect of product on the droplet size. This relation is quite complex because there is still the effect of adjuvants on the spray solution viscosity which is not known for all products available in the Brazilian market. Iost and Raetano (2010) evaluated the surface tension of several adjuvants, observed an inverse relation between the dynamic surface tension and contact angle of droplets, indicating that the higher surface tension the lower the surface wettability. There are other benefits associated with the use of adjuvants such as increase herbicidal activity found by Knezevic et al. (2010).

\section{Conclusions}

The effect of the adjuvant on droplets size was not detected with the increase and/or reduction of the recommended dose "D3", linearly, for the different adjuvants.

There was an interaction between product and dose on volume median diameter and the product "C" dose "D5" had the largest droplet size, which may be used as a drift reducer.

The different products tested did not reduce the values of the SPAN index compared to water.

The variables of the droplet spectrum $\mathrm{Dv}_{0.1}$, $\mathrm{Dv}_{0.5}, \mathrm{Dv}_{0.9}$ and SPAN responded independently to the dose of adjuvant.

\section{Literature Cited}

Carbonari, C.A.; Martins, D.; Marchi, S.R.; Cardoso, L.R. 2005. Efeito de surfactantes e pontas de pulverização na deposição de calda de pulverização em plantas de gramaseda. Planta Daninha, 23 (4): 725-729.

Cunha, J.P.A.R.; Peres, T.C.M.

2010. Influência de pontas de pulverização e adjuvante no controle químico da ferrugem asiática da soja. Acta Scientiarum Agronomy, 32 (4): 597-602.

Cunha, J.P.A.R.; Bueno, M.R.; Ferreira, M.C.

2010. Espectro de gotas de pontas de pulverização com adjuvantes de uso agrícola. Planta Daninha, 28: 1153-1158.
Cunha, J.P.A.; Teixeira, M.M.; Vieira, R.F.; Fernandes, H.C.; Coury, J.R.

2004. Espectro de gotas de bicos de pulverização hidráulicos de jato plano e de jato cônico vazio. Pesquisa Agropecuária Brasileira, 39 (10): 977-85.

Cunha, J.P.A.R.; Teixeira, M.M.; Coury, J.R.; E. Ferreira, L.R. 2003. Avaliação de estratégias para a redução da deriva de agrotóxicos em pulverizações hidráulicas. Planta Daninha, 21 (2): 325-332.

Di Oliveira, J.R.G.; Ferreira, M.C.; Román, R.A.A.

2010. Diferentes diâmetros de gotas e equipamentos para aplicação de inseticida no controle de Pseudoplusia includens. Engenharia Agrícola, 30 (1): 92-99. 
Green, J.M.; Beestman, G.B.

2007. Recently patented and commercialized formulation and adjuvant technology. Crop Protection, 26 (3): 320-327.

Iost, C.A.R.

2008. Efeito de adjuvantes nas propriedades físico-químicas da água e na redução de deriva em pulverizações sobre diferentes espécies de plantas daninhas. Botucatu: UNESP, 62 p. (Dissertação de Mestrado).

Iost, C.A.R.; Raetano, C.G.

2010. Tensão superficial dinâmica e ângulo de contato de soluções aquosas com surfactantes em superfícies artificiais e naturais. Engenharia Agrícola, 30 (4): 670-680.

Knezevic, S.Z.; Datta, A.; Scott, J.; Charvat, L.D.

2010. Application timing and adjuvant type affected Saflufenacil efficacy on selected broadleaf weeds. Crop Protection, 29: 94-99.

Lan, Y.; Hoffmann, W.C.; Fritz, B.K; Martins, D.E.; Lopez, L.E. 2007. Drift reduction with drift control adjuvants. ASABE. St. Joseph. 14 p. (paper n. 071060).

Minguela, J.V.; Cunha, J.P.A.R.

2010. Manual de aplicação de produtos fitossanitários. Viçosa: Editora Aprenda Fácil. 588.

Mota, A.A.B.; Antuniassi; U.R.; Oliveira; R.B.; Chechetto, R.G; Silva, A.C.A.

2010. Espectro de gotas da pulverização de herbicidas com e sem a adição de adjuvantes na calda. XXVII Congresso Brasileiro da Ciência das Plantas Daninhas 19 a 23 de julho de 2010 - Centro de Convenções - Ribeirão Preto - SP.

Gomes, F.P.

1990. Curso de estatística experimental. Piracicaba: Editora FEALQ. 468.
Oliveira, R.B.

2011. Caracterização funcional de adjuvantes em soluções aquosas. Botucatu: UNESP, 134 p. (Tese de Doutorado).

Roman, R.A.R.; Ferreira, M.C; Carvalho, G.F.G; Lemos, R.E;

Mendonça, L.G.

2009. Caracterização do tamanho de gotas de pontas de pulverização Turbo Teejet em função de vazão, pressão de trabalho e adjuvante. In: XXXVIII Congresso Brasileiro de Engenharia Agrícola. Juazeiro.

Spanoghe, P.; Eeckout, H.V.; Meeren, P.V.; Steurbaut, W.

2004. Effect of adjuvants on atomization of pesticides. Atomization and Sprays, 14 (6): 511-524.

Spanoghe, P.; De Schampheleire, M.; Der Meeren, P.V.; Steurbaut, W.

2007. Influence of agricultural adjuvants on droplet spectra. Pesticide Management Science, 63: 4-16.

Viana, R.G.; Ferreira, L.R.; Ferreira, M.C.; Teixeira, M.M.;

Rosell, J.R.; Tuffi Santos, L.D.; Machado, A.F.L.

2010 Distribuição volumétrica e espectro de gotas de pontas de pulverização de baixa deriva. Planta Daninha, 28 (2): 439-446.

Zhu, H.; Dexter, R.W.; Fox, R.D.; Reichard, D.L.; Brazee, R.D.; Ozkan, H.E.

1997 Effects of polymer composition and viscosity on droplet size of recirculated spray solutions. Journal of Agricultural Engineering Research, 67: 35-45.

Wolf, R.E.; Gardisser, D.R.

2003. Field comparisons for drift reducing/deposition aid tank mixes. In: ASAE/NAAA Technical Meeting, 37, St. Joseph. Proceedings... St. Joseph: ASAE, Paper No AA03-002. 
